\title{
Judgment in Maritime Boundary Dispute between Bangladesh and Myanmar: Significance and Implications under International Law
}

\author{
Abdullah Al Faruque
}

\section{INTRODUCTION}

The legal concept of the international maritime boundary is firmly established in international law. But the process by which these boundaries are determined in concrete situations will always have a sui generis character. ${ }^{2}$ As such, in their search for an appropriate solution, states are not obliged to reach their outcome by subjecting them to purely legal considerations. ${ }^{3}$ Rather, many relevant circumstances should be taken into account in delimiting a maritime boundary. The delimitation of a maritime boundary can be done through bilateral agreement or judicial settlement.

On March 14, 2012, in the case of Bangladesh/Myanmar, ${ }^{4}$ the Hamburgbased Law of the Sea Tribunal (ITLOS) delivered a historic judgment on the delimitation of the maritime boundary between Bangladesh and Myanmar. ${ }^{5}$ The Tribunal was asked to delimit three maritime boundar-

1 Dr. Abdullah al Faruque holds LL.B. (Hons.) and LL.M. degree from University of Dhaka, Bangladesh and PhD from Centre for Energy, Petroleum, Mineral Law and Policy, (CEPMLP), University of Dundee, UK. He is currently working as a Professor and Dean, Faculty of Law, University of Chittagong, Bangladesh. He can be contacted at faruquecu71@yahoo.com.

2 Gerard J. Tanja, The Legal Determination of International Maritime BOUNDARIES 306 (1990).

$3 \quad$ Id.

4 Dispute concerning Delimitation of the Maritime Boundary in the Bay of Bengal (Bangl. v. Myan.), Case No. 16, Order of Aug. 19, 2011, ITLOS Rep. 4, http://www. itlos.org/index.php?id=108\&L=1\%25252F [hereinafter ITLOS Case No. 16].

5 See D. H. Anderson, International Decision: Delimitation of the Maritime Boundary in the Bay of Bengal (Bangladesh/Myanmar), in_106 AMERICAN Journal of 
ies between Bangladesh and Myanmar: the territorial sea boundary, the single maritime boundary between the exclusive economic zones (EEZ) and continental shelves of the two states, and the boundary of the continental shelf beyond 200 nautical miles from the baselines of the two states. ${ }^{6}$ This dispute between Bangladesh and Myanmar was the first case before the ITLOS. This judgment has marked a distinctive and definitive legal achievement for Bangladesh. The dispute involved the delimitation of the territorial waters, exclusive economic zones and continental shelves of Bangladesh and Myanmar in the Bay of Bengal. The judgment also marks an important precedent that will be pertinent for resolving future maritime boundary disputes. The judgment is significant for Bangladesh for the following reasons.

First, the judgment bears great significance for Bangladesh. This is because its lawful claim on maritime zone has been recognized by the tribunal, which was previously disputed. Second, the long-standing dispute between the two countries has been resolved peacefully. Bangladesh always tried to settle the problem through bilateral negotiation; however, Myanmar was reluctant to settle it by bilateral negotiation or even by an international tribunal. Failing to reach an agreement through negotiations, Bangladesh opted to settle the dispute through a judicial means via a neutral third party. Amicable and peaceful settlement of the dispute by itself is a legal achievement for Bangladesh.

Third, a settled and demarcated maritime zone will definitely pave the way for Bangladesh to gain access to mineral resources in the maritime zone peacefully, which will accelerate its economic development. A long-standing dispute over maritime boundary delimitation with India and Myanmar remained a major stumbling block to exploration of these resources. Bangladesh had been deprived of her legitimate claim over maritime resources for a long time due to the uncertainty created by the absence of an agreed boundary. When there is no agreed boundary, exploration for hydrocarbon reserves can be delayed throughout a considerable area in and around the disputed maritime zones.

The overlapping claims of the disputing states necessitated a peaceful settlement for exploration of mineral resources in the demarcated mari-

INTERNATIONAL LAW 817 (2012).

6 ITLOS Case No. 16, supra note 4. 
time zone. Such necessity stemmed from the fact that the Bay of Bengal has become a very important area for hydrocarbon reserves. It should be mentioned that when Bangladesh declared its 28 offshore blocks in the Bay of Bengal in 2008, and when it invited bidders to explore in the blocks, both Myanmar and India opposed vehemently to Bangladesh initiatives and as a result, most of the international oil companies stayed away from the bidding. Now after the ITLOS judgment, Bangladesh will be able to explore mineral resources within its maritime boundary without any controversy.

This article attempts to explore the main aspects of the judgment. It will also analyze the implications and significance of the judgment from the perspective of the law of the sea and the interest of the parties to the dispute. This article also highlights important case law on the issue.

\section{HISTORY OF THE DISPUTE}

Since 1974, Bangladesh had been in negotiations with Myanmar for delimitation of the maritime boundary. ${ }^{7}$ The negotiations continued almost for four decades, but both countries failed to reach an agreement. According to Alam, "the only success achieved through this long negotiation was an agreement in the form of 'agreed minutes' for delimitation of 12 nautical miles (nm) territorial seas from the mouth of the Naaf River signed on November 23, 1974. The agreement delimited the maritime boundary within 12 nautical miles on the basis of the equidistance method between

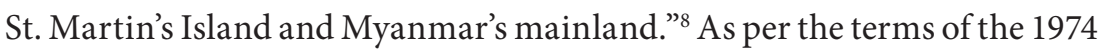
Agreed Minutes, signed by delegations of the two countries, Bangladesh

7 See M. Shah Alam \& Abdullah Al Faruque, The Problem of Delimitation of Bangladesh's Maritime Boundaries with India and Myanmar: Prospects for a Solution, 25 International Journal of Marine and Coastal Law 405 (2009); Jared Bissinger, The Maritime Boundary Dispute between Bangladesh and Myanmar: Motivation, Potential Solutions and Implications, 10 Asia Policy 203 (2010).

8 Khurshed Alam, Judgment in the Bangladesh-Myanmar Maritime Delimitation Case: Significant Precedent in the Law of the Sea (June 23, 2012) (unpublished thesis) (on file with Planning Academy, Nikhet, Dhaka). 
permitted Myanmar's vessels free and unimpeded navigation through Bangladesh's waters around St. Martin's Island to and from the Naaf River. ${ }^{9}$

In 1974, Bangladesh enacted the Territorial Waters and Maritime Zones Act. Bangladesh is the first South Asian country to enact such a law. ${ }^{10}$ Bangladesh adopted the depth method for measuring the baseline, and declared $12 \mathrm{~nm}$ as territorial sea, $18 \mathrm{~nm}$ as contiguous zone, $200 \mathrm{~nm}$ as economic zone, and $350 \mathrm{~nm}$ as continental shelf from the baseline under this Act. However, India and Myanmar opposed the provisions on depth method baseline mentioned in the Act.

In 2001, Bangladesh ratified the United Nations Convention on the Law of the Sea 1982 (UNCLOS). ${ }^{11}$ Bangladesh claimed a continental shelf up to the last point of the continental margin, which exceeds $200 \mathrm{~nm} \cdot{ }^{12} \mathrm{In}$ 2011, Bangladesh submitted its claim on the continental shelf to the Commission on the Limits of the Continental Shelf (CLCS), which is responsible for examining the claims by individual states to an outer continental shelf.

It should be mentioned that Bangladesh is tucked between Myanmar and India in the concave north coast of the Bay of Bengal. ${ }^{13}$ Apart from this, Bangladesh's own coast is concave in nature. ${ }^{14}$ As a result, if maritime delimitation is carried out by an equidistance line, Bangladesh would be virtually cut-off from the high sea and its maritime area would be confined to $130 \mathrm{~nm}$ as opposed to its claim for $200 \mathrm{~nm}$ EEZ and $350 \mathrm{~nm} .{ }^{15}$ Bangladesh proposed an equitable solution of the dispute with Myanmar. But having failed to resolve the problem through bilateral negotiation, the Government of Bangladesh was compelled to go for judicial settlement of the dispute. ${ }^{16}$ In September 2009, Bangladesh initiated Arbitral proceedings. A Notice of Arbitration was issued on October 8,2009 to Myanmar under Part XV

9 Moin Ghani, A ‘Great Win’ for Bangladesh, The Daily Star (Mar. 27, 2012), http:// archive.thedailystar.net/newDesign/news-details.php?nid=227828.

10 Harjeet et al., Pentagon's South Asia Defence and Strategic Yearbook 2010134 (2009).

11 ITLOS Case No. 16, supra note 4, at 32.

12 Id.

13 Ghani, supra note 9.

14 ITLOS Case No. 16, supra note 4, at 276.

$15 \quad I d$. at 458.

$16 \quad I d$. at 1. 
of the UNCLOS for delimitation of territorial sea, the exclusive economic zone and the continental shelf in accordance with international law. ${ }^{17} \mathrm{~A}$ few weeks later Myanmar deposited a "Declaration" under UNCLOS accepting the jurisdiction of the ITLOS to hear the dispute. ${ }^{18}$ Bangladesh itself then lodged a similar Declaration on December 12,2009, initiated proceedings before the ITLOS on the next day, and withdrew the separate arbitral proceedings. Myanmar withdrew its Declaration in January 2010, presumably to prevent other proceedings being brought against it before the ITLOS. ${ }^{19}$ Howevr, it was determined that this did not affect the jurisdiction of the ITLOS over the proceedings that had already commenced. ${ }^{20}$

\section{LAW APPLICABLE TO THE DISPUTE}

The legal provisions that are applicable in the maritime delimitation are laid down in UNCLOS. According to Articles 3, 4, and 5 of UNCLOS, the territorial sea extends to $12 \mathrm{~nm}$ from the baseline and in the territorial sea, and the coastal state has full sovereign rights over the territorial sea similar to the rights that a state has over its land territory. ${ }^{21}$ According to Articles 55 and 57, the EEZ extends $200 \mathrm{~nm}$ from the baseline and an area beyond and adjacent to the territorial sea. ${ }^{22}$ In the EEZ, the coastal state has sovereign rights for exploring, exploiting, conserving and managing natural resources. ${ }^{23}$ According to Article 76, the continental shelf is the seabed and the subsoil that extends from the coast throughout the natural prolongation of the land territory. ${ }^{24}$ The outer limit of the continental shelf is either the outer edge of the continental margin, or to a distance of

17 Id.

$18 \quad I d$. at 3.

19 Id. at 8.

$20 \quad I d$. at 9.

21 United Nations Convention on the Law of the Sea, arts. 3, 4, 5, Dec. 10, 1982, U.N. Doc. A/Conf.62/422, reprinted in The Law of the Sea: Official Text of the United Nations Convention on the Law of the Sea with Annexes And Index, U.N. Sales No. E.83V.5 (1983) [hereinafter UNCLOS].

22 Id. arts. 55, 57.

23 Id.

$24 I d$. art. 76. 
$200 \mathrm{~nm}$ from the baseline where the outer edge does not extend up to that distance. ${ }^{25}$ Thus, continental shelf can extend much further than the EEZ depending on geographical circumstances. ${ }^{26}$

Regarding delimitation of the territorial sea, Article 15 of UNCLOS provides for delimitation to be effected by the equidistance principle. ${ }^{27}$ The equidistance line is the median line - every point of which is equidistant from the nearest points on the baseline of the adjacent or opposite States. ${ }^{28}$ For delimitation of the EEZ and continental shelf up to $200 \mathrm{~nm}$, Article 74 of UNCLOS states that delimitation shall be effected by agreement on international law to achieve an equitable solution, which is practically done by drawing a provisional equidistance line from the selected base points from the coastlines of the parties and then adjusting the line for relevant circumstances, if any, to ensure "equity". ${ }^{29}$ The proportionality test is applied in light of the ratio between the relevant coasts of the two States to achieve an equitable result. ${ }^{30}$

\section{SPECIAL GEOGRAPHICAL FEATURES OF THE MARITIME ZONE OF BANGLADESH}

Many conflicting territorial claims arise from the tendency of states to expand by acquiring additional territory through creeping annexation. The conflicting claims should be resolved through negotiation and mutuality of interests. ${ }^{31}$ This becomes especially important when each delimitation problem involves a situation that has its own unique characteristics to be taken into account. India, Bangladesh, and Myanmar have many variations in their coastal configurations as well as in their geographical, geological, and topographical situations. ${ }^{32}$ The southern half of Bangladesh is the joint delta of three major rivers, namely the Ganges, the Brahmaputra, and

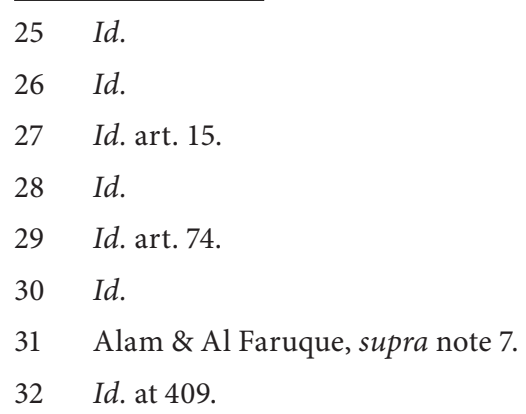


the Meghna. ${ }^{33}$ These rivers run from the Himalayan Ranges to the Bay of Bengal through Bangladesh. The geomorphological features of Bangladesh's coastline create difficulties in fixing the baseline from which the maritime zones can be measured. ${ }^{34}$ The coastline of Bangladesh has the following geographical characteristics: deltaic coastline, which is deeply indented; erosion and sedimentation continuously affect adjacent coastal waters; a highly unstable coastline is evident at low tide; navigable channels in the coastline change continuously, requiring frequent surveys and demarcation. ${ }^{35}$

In practice, in determining maritime boundaries, geographical considerations play a predominant role. Other factors, such as economic, ecological, security, and geomorphological factors are taken into account, but are given relatively less weight. ${ }^{36}$ Articles 74 and 83 of the UNCLOS contain no reference to the equidistance principle, which may be applied only insofar as it leads to an equitable solution. ${ }^{37} \mathrm{~A}$ boundary that might be equitable for EEZ purposes may not be equitable for continental shelf purposes. ${ }^{38}$ Because of the different considerations that are relevant to achieving an equitable solution in each case, such as, for example, the location of fish stocks in the case of the EEZ, and the geological characteristics, the seabed and the location of seabed mineral deposits in the case of the continental shelf, each maritime boundary dispute is unique. ${ }^{39}$ The existing maritime dispute between Bangladesh and her neighbors is also unique and requires a solution on the basis of the application of equitable principles, taking into consideration a variety of factors. ${ }^{40}$

Bangladesh has a concave coast. ${ }^{41}$ Countries with concave coasts require unconventional solutions. ${ }^{42}$ Therefore, per UNCLOS Article 15, rules for

$\begin{array}{ll}33 & I d . \\ 34 & I d . \\ 35 & I d . \text { at } 410 . \\ 36 & I d . \\ 37 & I d . \\ 38 & I d . \\ 39 & I d . \\ 40 & I d . \\ 41 & I d . \\ 42 & I d .\end{array}$


special circumstances should be applied for delimitation of a maritime boundary. ${ }^{43}$ The special geographical circumstances warrant that any delimitation whether agreed or determined by a third party, must result in an equitable solution. ${ }^{44}$ Although in principle there is no limit to the factors relevant to the determination of such an equitable demarcation, there are some established criteria for such a demarcation. ${ }^{45}$

\section{THE EQUIDISTANCE VS. THE EQUITABLE APPROACH}

It is well settled that application of the principle of equidistance, which is more formal and mechanical in nature, does not always ensure justice. ${ }^{46}$ A median line based on the equidistance principle can be drawn on the basis of coastal geography and is controlled by the relevant points on the territorial sea baseline. ${ }^{47}$ On the other hand, the equitable principle is more flexible and open-ended. ${ }^{48}$ It is generally accepted that the median-line delimitation on the basis of the equidistance principle between opposite coasts results in an equitable solution, particularly if the coasts in question are nearly parallel. ${ }^{49} \mathrm{On}$ the other hand, in the case of adjacent coasts, the application of the equitable approach is usually employed for delimitation in order to ensure an equitable solution. ${ }^{50}$ The UNCLOS and existing judicial decisions also endorse the equitable principle. ${ }^{51}$ Although the UNCLOS sets no criteria to be used to determine an equitable delimitation, existing state practice and judicial decisions suggest that the equitable principle of delimitation always takes relevant circumstances into consideration. ${ }^{52}$ The relevant circumstances can include any or all of the following: political, strategic and historical considerations; legal regime considerations; eco-

\begin{tabular}{ll}
\hline 43 & $I d$. \\
44 & $I d$. \\
45 & $I d$. \\
46 & $I d$. at 417. \\
47 & $I d$. \\
48 & $I d$. \\
49 & $I d$. \\
50 & $I d$. \\
51 & $I d$. \\
52 & $I d$.
\end{tabular}


nomic and environmental considerations; other geographic considerations; the use of islands, rocks, reefs and low tide elevations; baseline considerations; geological and geomorphological considerations; proportionality of the area to be delimited including coastal front considerations; and different technical methods that could be employed. ${ }^{53}$ However, amongst these relevant circumstances, special circumstances of coastal geography have a fundamental role in arriving at an equitable solution for maritime delimitation problems. ${ }^{54}$ Thus, the application of the equitable principle should be warranted by the existence of special circumstances. In the Anglo-French case, the tribunal unambiguously stated:

[T] he appropriateness of the equidistance or any other method for the purposes of effecting an equitable delimitation is a function or reflection of the geographical and other relevant circumstances of each case. The choice of the method or methods of delimitation in any given case, whether under the 1958 Convention or customary law, has therefore to be determined in the light of those circumstances and of the fundamental norm that the delimitation must be in accordance with equitable principles. ${ }^{55}$

As mentioned earlier, the existence of relevant circumstances is one of the factors considered by the courts in deciding on the basis of the title of the coastal state. Another factor is that a boundary line should not be drawn in such a way that encroaches on or cuts off areas that more naturally belong to one party than the other. ${ }^{56}$ The concavity and/or convexity of the coast is considered as an important example of special or relevant circumstances in equitable delimitation. ${ }^{57}$ For instance, maritime agreements between the Federal Republic of Germany and the Netherlands (1971), and Denmark and the German Democratic Republic (1988), where one coast is convex and the other concave; Colombia-Panama (1976), where convexities and concavities on the two coasts are different, and France-Spain (1974), are

\footnotetext{
53 Victor Prescott et al., The Maritime Political Boundaries of THE WORLD 220-21 (2d ed. 2005).

$54 \quad$ Id. at 222.

55 Id. at 97.

56 Robin Rolf Churchill \& Alan Vaughn lowe, The Law of the Sea 187 (3d ed. 1999).

57 Alam \& Al Faruque, supra note 7, at 417.
} 
based on the equitable principle. ${ }^{58}$ It has also been observed in the Libya/ Malta case:

[S]ince the equidistance line is based on a principle of proximity and therefore controlled only by salient coastal points, it may yield a disproportionate result where the coast is markedly irregular or markedly concave or convex. In such cases, the raw equidistance method may leave out of the calculation appreciable lengths of the coast, while at the same time giving undue influence to others merely because of the shape of the coastal relationships. ${ }^{59}$

Bangladesh's delimitation problems qualify for the application of equity because of special circumstances. Bangladesh's mostly adjacent rather than opposite location of maritime borders, together with the concave, unstable, and broken nature of her coastline, her historical title in the Bay of Bengal and dependence of her coastal people on living and non-living resources of the sea-all these special circumstances and relevant factors support the basis of the claim of Bangladesh for the delimitation of maritime boundaries on the equitable principle. ${ }^{60}$ In such a case, therefore, according to UNCLOS Article 74, "the equidistance principle is not applicable and the boundary lines in question are to be drawn by agreement between the parties on the basis of international law in order to achieve equitable solution taking into account the configuration of the coast, the length of the coast and other relevant factors." ${ }^{\prime \prime}$

The principle of equitable demarcation is firmly rooted in the international law of the sea and emanates from the idea of uniqueness of each boundary. This uniqueness is the result of a great variety of geographical features of the continental shelf, which indicates that it is very difficult to posit any fixed rule governing the establishment of maritime boundaries

58 Prosper Weil, Geographic Considerations in Maritime Delimitation, in International Maritime Boundaries 115 (2014).

59 Continental Shelf (Libya v. Malta), Judgment, 1985 I.C.J. 13 (June 3).

60 M. Shah Alam, Maritime Border Delimitation, The Daily Star, (Feb. 9, 2009), http://archive.thedailystar.net/newDesign/print news. php?nid=74987.

61 Alam \& Al Faruque, supra note 7, at 419-20. 
between states. ${ }^{62}$ The idea of uniqueness of each boundary finds significant support in the jurisprudence of the ICJ and arbitral tribunals dealing with maritime boundary disputes. In the Tunisia/Libya case, the ICJ declared:

[C]learly each continental shelf case in dispute should be considered and judged on its own merits, having regard to its peculiar circumstances; therefore, no attempt should be made here to over conceptualize the application of the principles and rules relating to the continental shelf. ${ }^{63}$

In the Anglo-French Award, the court of arbitration noted that: "the appropriateness of the equidistance method or any other method for the purpose of effecting an equitable delimitation is a function or reflection of the geographical and other relevant circumstances of each particular case."64

The ICJ and arbitral tribunals dealing with the delimitation of maritime boundaries have consistently held that the equidistance principle is not a mandatory rule of international law and that it does not enjoy any priority or preferential status. ${ }^{65}$ In fact, the principle of equidistance has been unable to attract a consensus among members of the international community due to its rigidity. ${ }^{66}$

\section{DELIMITATION OF THE TERRITORIAL SEA}

Regarding the delimitation of the territorial sea boundary, Bangladesh argued that the boundary had already been delimited in the Agreed Minutes of 1974 and 2008, signed by the two delegation heads during negotiations over maritime boundaries. However, Myanmar denied that any such binding agreement should be considered as a treaty. It was argued by Myanmar that the Agreed Minutes were no more than a record of a conditional understanding and were not intended to create legal obligations. The ITLOS

62 L. D. M. Nelson, The Roles of Equity in the Delimitation of Maritime Boundaries, 84 American Journal of InTERnational LaW 837 (1990).

63 Continental Shelf (Tunis. v. Libya), Judgment, 1982 I.C.J. 18, 92, 132 (Feb. 24).

64 Anglo-French Continental Shelf Arbitration (Can. v. Fr.), 18 I.L.M. 397, 426, g 97 (1979).

65 Alam \& Al Faruque, supra note 7, at 421.

$66 I d$. 
held that those Minutes did not constitute an agreement and accordingly proceeded to delimit the territorial sea.

As mentioned above, in the absence of any agreement between the states concerned, Article 15 of UNCLOS provides that the territorial sea boundary will be delimited on an equidistance principle unless it is necessary by reason of historical title or other special circumstances to delimit the territorial seas in another way. ${ }^{67}$ As no party to the dispute raised the issue of historical title to any of the waters concerned, the ITLOS applied the equidistance principle in delimitation of territorial waters considering the base points used by the parties and recognized that Bangladesh has the right to a $12 \mathrm{~nm}$ territorial sea around St. Martin's Island. ${ }^{68}$

In this regard, Myanmar has raised the issue of St. Martin's Island as a special circumstance in the context of the delimitation of the territorial sea and argued that St. Martin's Island should be totally ignored in such maritime formation. ${ }^{69}$ But the ITLOS observed that the Island is situated within the $12 \mathrm{~nm}$ territorial sea limit from Bangladesh's mainland coast and concluded that the island should be given full effect in drawing the delimitation line of the territorial sea between the Parties. ${ }^{70}$ Though the ITLOS observed that St. Martin's Island is a significant maritime feature by virtue of its size and population and the extent of the economic and other activities involved in it; nevertheless, it determined that there is no compelling reason that would justify treating the island as a special circumstance. ${ }^{71}$

Accordingly, the ITLOS drew the boundary of the territorial sea, which begins at the terminus of the land frontier in the mouth of the Naaf River, and runs generally southward, following the equidistance line between base points on St. Martin's Island and the mainland coast of Myanmar. This territorial water delimited by the ITLOS is almost identical to the boundary agreed in 1974 as argued by Bangladesh. ${ }^{72}$

67 UNCLOS, supra note 21, art. 15

68 ITLOS Case No. 16, supra note 4, at 129.

69 Id. gg 131-32.

$70 \quad$ Id. 99 149-51.

71 Id. $9 g$ 151-52.

72 See Joint Declaration of Judges ad hoc Mensah and Oxman 2, available at http://www.itlos.org/fileadmin/itlos/documents/cases/case_no_16/C16.decl. Mensah-Oxman.rev.E.pdf. 

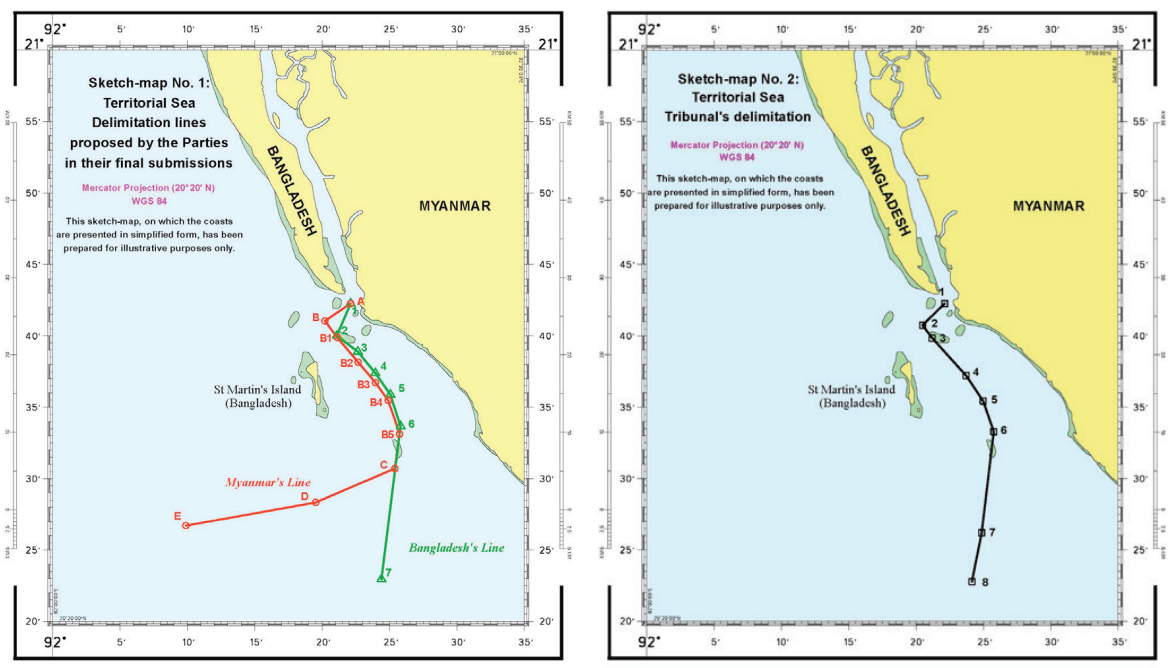

\section{DELIMITATION OF EXCLUSIVE ECONOMIC ZONE}

For delimitation of the EEZ boundary between the two states, Myanmar demanded the application of the equidistance principle for delimitation, while Bangladesh always sought to delimitate its maritime boundary on the basis of the application of the equitable principle. ${ }^{73}$ It was anticipated that the delimitation of the EEZ boundary on the basis of the equidistance principle would result in the annexation of much of the sea area of Bangladesh by Myanmar. ${ }^{74}$ Bangladesh would get only a tiny share in the Bay of Bengal, and it would be virtually cut-off from accessing the high sea if it was delimited on the equidistance principle. The Tribunal applied the equitable principle instead of equidistance to resolve the dispute. ${ }^{75}$

It is widely recognized by international courts and tribunals that each delimitation problem involves a situation that has its own unique characteristics to be taken into account. ${ }^{76}$ Special circumstances of coastal geography have a fundamental role in arriving at an equitable solution of Daily StAR (Apr. 21, 2012), http://archive.thedailystar.net/law/2012/04/03/index. $\underline{\text { htm. }}$.

$74 \quad I d$.

75 Id.

$76 \quad I d$. 
maritime delimitation problems. ${ }^{77}$ As mentioned above, Bangladesh has a concave coast, ${ }^{78}$ and countries with concave coasts require unconventional solutions. ${ }^{79}$ Another factor is that a boundary line should not be drawn in such a way that encroaches on or cuts off areas that more naturally belong to one party than the other. ${ }^{80}$ Special circumstances and relevant factors such as Bangladesh's mostly adjacent rather than opposite location of maritime borders, together with the concave, unstable, and broken nature of her coastline ${ }^{81}$ all support the basis of the claim of Bangladesh for the delimitation of maritime boundaries on the equitable principle. ${ }^{82}$

Bangladesh argued that delimitation of the exclusive economic zone, continental shelf, and the area beyond $200 \mathrm{~nm}$ should be based on equitable principle. ${ }^{83}$ Bangladesh did not identify any base points since it opposed the equidistance method. ${ }^{84}$ In particular, Bangladesh stated that Myanmar's claimed equidistance line is inequitable because of the cut-off effect it produces. ${ }^{85}$ Bangladesh argued that on account of the specific configuration of its coast and of the double concavity characterizing it, the Tribunal should apply the angle-bisector method in delimiting the EEZ and the continental shelf. ${ }^{86}$ In its view, this method would eliminate the inequity associated with equidistance and lead to an equitable result. ${ }^{87}$

On the other hand, Myanmar strongly argued for application of the equidistance method and told the ITLOS that the angle-bisector method advanced by Bangladesh would produce an inequitable result. ${ }^{88}$ However, the ITLOS did not fully agree to all of the arguments of Bangladesh. ${ }^{89}$ They

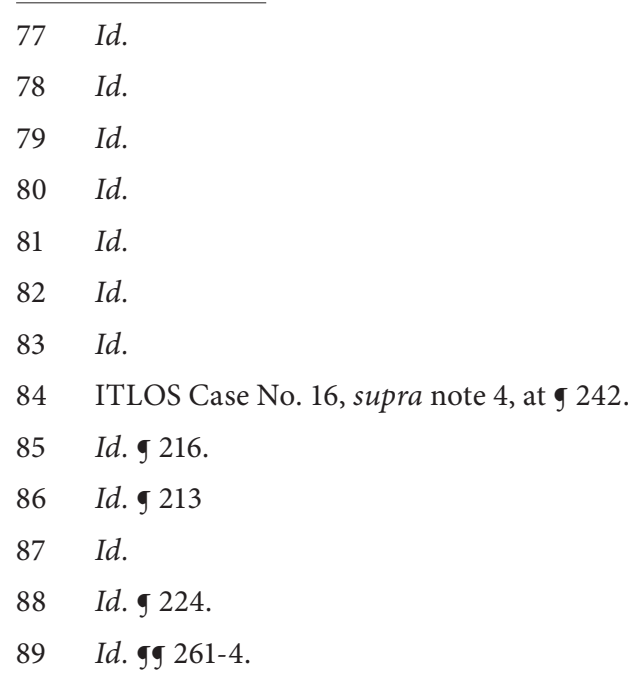


also rejected the arguments of Myanmar that there was no relevance for placing their suggested base points. ${ }^{90}$ In contrast, Bangladesh had identified several possible relevant base points that were acceptable. ${ }^{91}$ The ITLOS added its own base points to lead to a more equitable provisional equidistance line. ${ }^{92}$ It accepted that it was necessary to adjust the equidistance line to take into account the concavity of the coast.

On this point, the ITLOS observed that the goal of achieving an equitable result must be the paramount consideration guiding the delimitation. ${ }^{93}$ In this regard, the ITLOS adopted a three-stage approach. At the first stage it constructed a provisional equidistance line, based on the geography of the Parties' coasts and mathematical calculations. ${ }^{94}$ At the second stage, after drawing the provisional equidistance line, it has made an adjustment so that the line produces an equitable result. ${ }^{95}$ At the third and final stage, the ITLOS considered that the adjusted line should not result in any significant disproportion between the ratio of the respective coastal lengths and the ratio of the relevant maritime areas allocated to each Party. ${ }^{96}$ In adjusting the provisional line, the ITLOS has considered relevant circumstances with a view to achieving an equitable solution.

At this point, Bangladesh highlighted three main geographical and geological features as relevant circumstances such the "concave shape of Bangladesh's coastline," location of St. Martin's Island and the Bengal depositional system as a proof of natural prolongation of the landmass of Bangladesh. ${ }^{97}$ Myanmar contended that relevant circumstances did not exist that may lead to an adjustment of the provisional equidistance line..$^{98}$ But the ITLOS observed that the coast of Bangladesh is manifestly

\section{Id. 264.}

91 James Harrison, Judgment in Bangl.-Myan. Maritime Boundary Dispute, InT'L L. ObServer (Mar. 14, 2012, 1:15 PM), http://www.internationallawobserver. eu/2012/03/15/judgment-in-bangladesh-myanmar-maritime-boundary-dispute.

92 Id.

93 ITLOS Case No. 16, supra note 4, at 235.

$94 \quad$ Id. 240.

95 Id.

$96 \quad I d$.

$97 \quad I d .9276$.

$98 \quad I d .9289$. 
concave, ${ }^{99}$ and further noted that on account of the concavity of the coast in question, the provisional equidistance line it constructed produces a cut-off effect on the maritime projection of Bangladesh. ${ }^{100}$ Therefore, the ITLOS adjusted the line to achieve an equitable solution. ${ }^{101}$ However, the ITLOS did not consider St. Martin's Island and the Bengal depositional system as relevant circumstances. ${ }^{102}$

Another important point is that the ITLOS decided that in relation to the delimitation of the EEZ and continental shelf, a single maritime boundary should be drawn. ${ }^{103}$
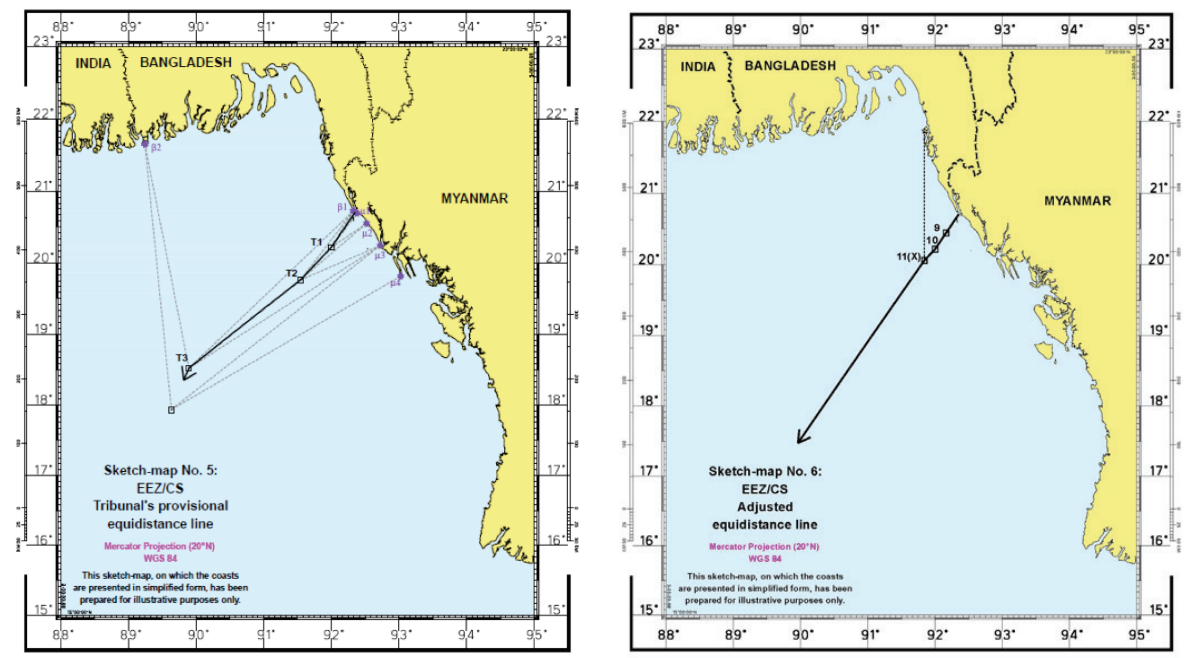

\section{DELIMITATION OF CONTINENTAL SHELF BEYOND 200 NM}

Bangladesh claimed that the ITLOS has jurisdiction to delimit the continental shelf beyond $200 \mathrm{~nm} \cdot{ }^{104}$ Myanmar objected claiming that the ITLOS has no such jurisdiction to do so. The tribunal considered first whether it had jurisdiction to delimit the continental shelf boundary beyond 200

\begin{tabular}{ll}
\hline 99 & Id. 291. \\
100 & Id. 293. \\
101 & $I d$. \\
102 & $I d .9265$. \\
103 & $I d .9 g 180-81$. \\
104 & Id. at 41.
\end{tabular}


$\mathrm{nm} \cdot{ }^{105}$ The ITLOS found that it had jurisdiction to delimit the continental shelf beyond $200 \mathrm{~nm} .{ }^{106}$ Secondly, the tribunal pondered, if it had such jurisdiction, whether it was appropriate to exercise that jurisdiction. ${ }^{107}$ According to UNCLOS, a state's continental shelf may extend beyond $200 \mathrm{~nm}$ only if certain geological and geomorphological criteria set out in Article 76 are fulfilled. The ITLOS decided that it was appropriate and competent to delimit the continental shelf beyond $200 \mathrm{~nm}$ as both the parties claimed overlapping entitlements to the continental shelf beyond $200 \mathrm{~nm}$.

Myanmar's argument that Bangladesh's continental shelf cannot extend beyond $200 \mathrm{~nm}$ was rejected by the ITLOS. The ITLOS recognized that Bangladesh has a maritime zone up to $200 \mathrm{~nm}$ from its baseline and has also an entitlement to the continental shelf beyond $200 \mathrm{~nm} .{ }^{108}$ The ITLOS recognized that both Bangladesh and Myanmar have entitlements to a continental shelf extending beyond $200 \mathrm{~nm} .{ }^{109}$ The ITLOS observed that the concavity of the Bangladesh coast would be a relevant circumstance for the purpose of delimiting the continental shelf even beyond 200 $\mathrm{nm} .{ }^{110}$ This is the first time that any tribunal has exercised its jurisdiction in delimiting the continental shelf beyond $200 \mathrm{~nm}$. However, the Tribunal did not take into account geological and geomorphological circumstances such as natural prolongation as relevant factor argued by Bangladesh in delimitation.

The ITLOS decided that the boundary between the parties' overlapping continental shelves beyond $200 \mathrm{~nm}$ should be a continuation of the single maritime boundary until it reached the area where the rights of third States might be affected. ${ }^{111}$ Thus, the adjusted equidistance line extending beyond $200 \mathrm{~nm}$ indicated by the ITLOS does not have a terminus point. The ITLOS noted that it will continue "until it reaches the area where the rights of third party States may be affected." ${ }^{\prime 12}$ Usually, the limit of the

\begin{tabular}{ll}
\hline 105 & Id. at 45. \\
106 & Id. gg $360-63$. \\
107 & Id. g 371. \\
108 & Id. g 449. \\
109 & Id. \\
110 & Id. gg 461-462. \\
111 & Id. g 462. \\
112 & Id.
\end{tabular}


outer edge of the continental margin could be $350 \mathrm{~nm}$ from the coast. The ITLOS distinguished between its own role to "delimit" the continental shelf and the UN CLCS, a separate body established under UNCLOS. In other words, the ITLOS did not define the terminus of the continental shelf, leaving it to the CLCS. The final and binding outer limit of the shelf must be established by a coastal state on the basis of the recommendation of the Commission. ${ }^{113}$

\section{ACCESS TO GREY AREA}

According to Churchill, "grey zones" are liable to occur whenever a single maritime boundary is not an equidistance line and especially where such a line is extended to form the boundary of the continental shelf beyond 200 nm. ${ }^{114}$ The recognition of the tribunal that both countries have a continental shelf beyond $200 \mathrm{~nm}$ resulted in a small "grey area," which is within 200 nm of Myanmar's coast, but not on the Bangladesh side of the delimitation line. This "grey area” is a place where Bangladesh's outer continental shelf claims overlaps with Myanmar's $200 \mathrm{~nm}$ EEZ. In this "grey area," the ITLOS gave Myanmar the right to use the water column whereas the right of seabed, within the EEZ of Myanmar, was granted to Bangladesh. The ITLOS called upon each party to exercise its rights in this grey area with due regard for the rights and duties of the other, following the principle in Article 56 of the UNCLOS. This "grey area" was not delimited by the ITLOS. After considering the difficulties it presented, the ITLOS noted that there existed many ways for the parties to reach a cooperative agreement on this limited area, indicating a joint development or unitization. However, the ITLOS provided Bangladesh access to this grey area.

$113 \quad$ Id. 379.

114 Churchill, supra note 56, at 137-52. 


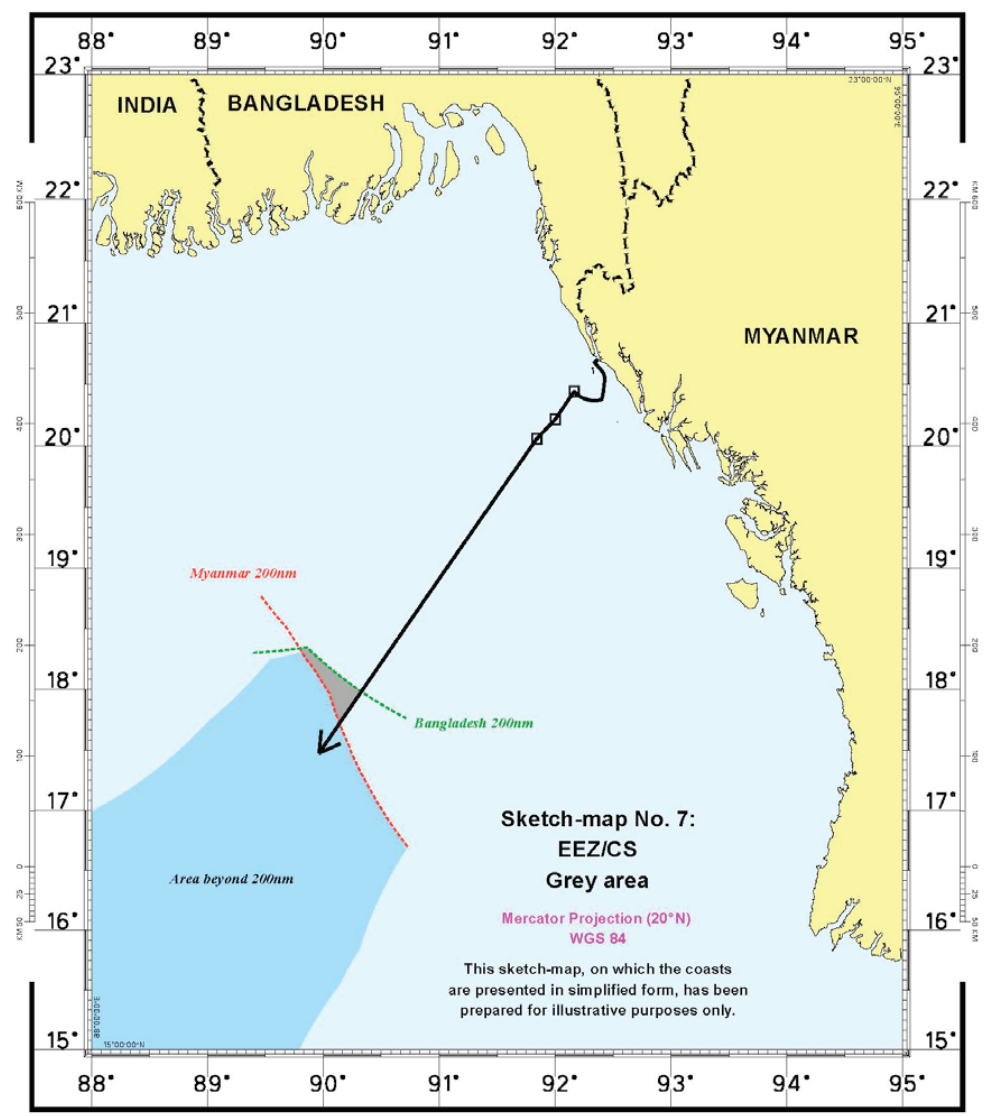

10. DISPROPORTIONALITY TEST

For the purpose of the delimitation of the exclusive economic zone and the continental shelf, the relevant coast of the Parties is a significant factor. In this regard, the ITLOS considered that, for the purpose of determining any disproportionality in respect of areas allocated to the Parties, the relevant area should include maritime areas subject to overlapping entitlements of the Parties to the present case. ${ }^{115}$

Regarding the issue of relevant coasts in determining delimitation of maritime zones, Bangladesh argued that its entire coast is relevant. ${ }^{116}$ Myan-

$\begin{array}{ll}115 & \text { Id. } \\ & 493 . \\ 116 & \text { Id. } 186 .\end{array}$


mar opposed this argument. ${ }^{117}$ Bangladesh measures its relevant coast as $421 \mathrm{~km} .{ }^{118}$ Regarding Myanmar's relevant coast, Bangladesh argued that it extends from mouth of the Naaf River up to Cape Bhiff. ${ }^{119}$ Myanmar on the other hand argued that the coasts of Bangladesh in the Meghna estuary do not constitute the relevant coast. ${ }^{120}$ Myanmar measured the relevant coast for Bangladesh as only $364 \mathrm{~km}$ and $740 \mathrm{~km}$ for its own. ${ }^{121}$ The proportion was approximately 1:2 in favor of Myanmar.

However, the Tribunal decided the relevant coast on its own and accepted Bangladesh's argument to consider the Meghna estuary as part of the relevant coast. ${ }^{122}$ The Tribunal calculated the size of the relevant area to be approximately 283,471 square $\mathrm{km} \cdot{ }^{123}$ Taking the whole coast of Bangladesh as relevant, the Tribunal held that the length of the relevant coast of Bangladesh is $413 \mathrm{~km},{ }^{124}$ while that of Myanmar is $587 \mathrm{~km} .{ }^{125}$ The ratio of the length of the relevant coasts of the Parties is 1:1.42 in favor of Myanmar. ${ }^{126}$ The ITLOS noted that its adjusted delimitation line allocates approximately 111,631 square $\mathrm{km}$ of the relevant area to Bangladesh and approximately 171,832 square $\mathrm{km}$ to Myanmar. ${ }^{127}$

Then, the ITLOS checked whether the adjusted equidistance line has caused a significant disproportion by reference to the ratio of the length of the coastlines of the Parties and the ratio of the relevant maritime area allocated to each Party. ${ }^{128}$ The ITLOS found that this ratio does not lead to any significant disproportion in the allocation of maritime areas to the

\begin{tabular}{ll}
\hline 117 & Id. g 188. \\
118 & Id. g 187. \\
119 & Id. g 192. \\
120 & Id. g $188-89$. \\
121 & Id. g $190,197$. \\
122 & Id. g 200. \\
123 & Id. 496. \\
124 & Id. g 202. \\
125 & Id. g 204. \\
126 & Id. g 498. \\
127 & Id. g 499. \\
128 & Id. g 240.
\end{tabular}


Parties relative to the respective lengths of their coasts. ${ }^{129}$ According to the ITLOS rather, this ratio produced an equitable solution. ${ }^{130}$

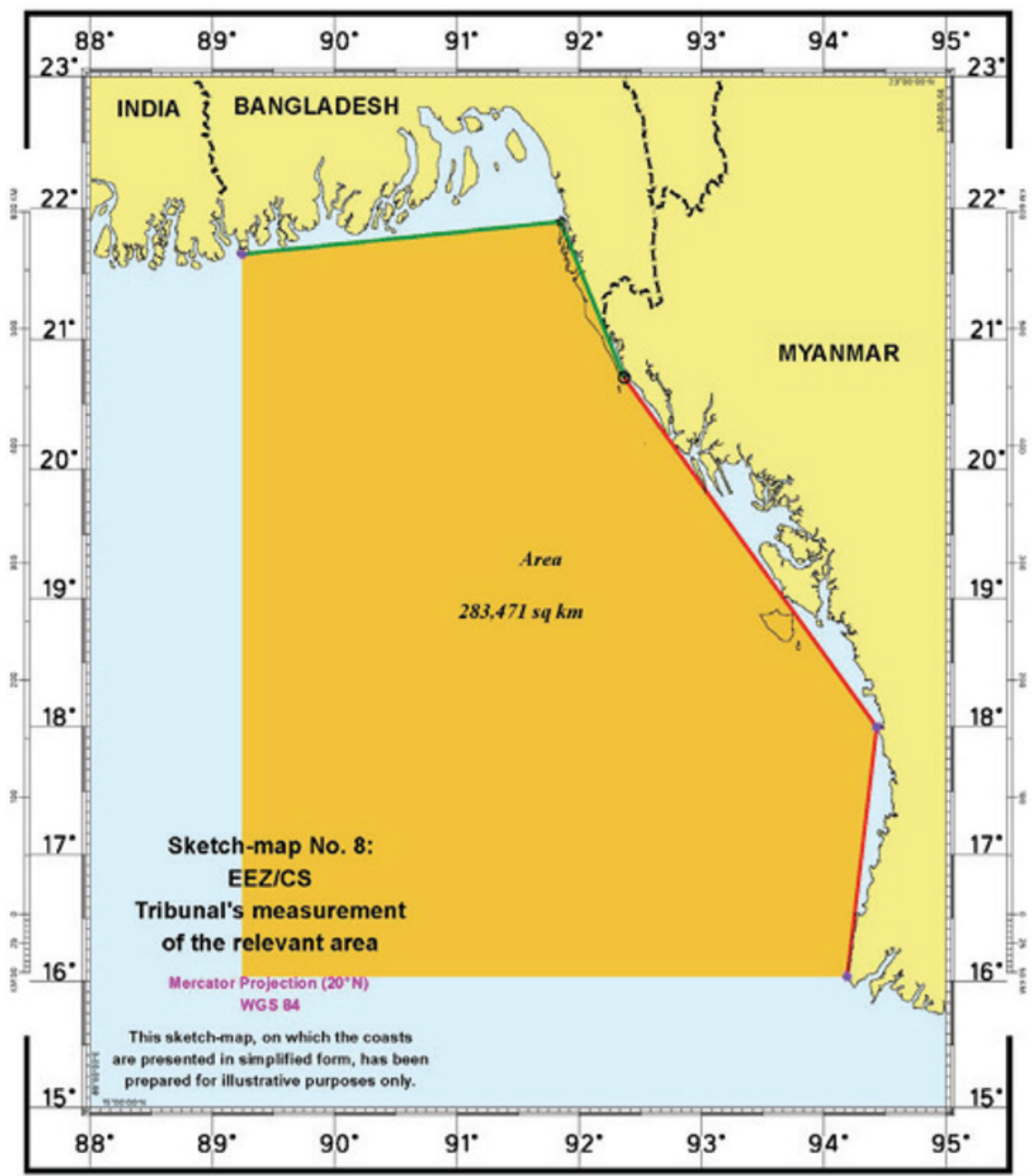

129 Id. 499.

130 Id. 


\section{CONCLUSION}

This judgment has made a landmark precedent in the history of the law of the sea. The judgment sets significant precedents on the following three important issues of maritime boundary delimitation: it represents a settled case law of international courts and tribunal regarding delimitation of single maritime boundaries, and for the first time, an international tribunal or court has delimited a continental shelf boundary beyond $200 \mathrm{~nm}$ and considered the issue of the "grey area."131 It established a single maritime boundary starting from the agreed terminus of the land boundary and delimiting the territorial sea, the EEZ and continental shelf of both parties. While the Tribunal applied the equidistance principle to delimit the territorial sea, it applied mainly an equitable method to delimit the EEZ and continental shelf both within and beyond $200 \mathrm{~nm}$. In terms of more specific points of judgment, it can be gleaned that although the ITLOS has rejected some of the arguments of Bangladesh, such rejection did not affect substantially what Bangladesh wanted from the judgment. In fact, Bangladesh received a greater share in the Bay of Bengal through the judgment, which was not otherwise possible through bilateral negotiation. On the other hand, Myanmar also received a much larger share of the "relevant area" in the maritime zone. In this way, the judgment created a "win-win" result for both states.

The judgment establishes defined boundaries for both parties to the disputes, which will eventually enable them to explore natural resources. From Bangladesh's perspective, this judgment will undoubtedly have great persuasive value in the resolution of the dispute between Bangladesh and India on maritime delimitation, which is currently pending before the Permanent Court of Arbitration in The Hague. It should be mentioned that Bangladesh instituted separate proceedings in its arbitration against India under Annex VII of the UNCLOS to settle its maritime boundary with the latter.

Currently, international tribunals try to apply a coherent interpretation of previous judgments on the same issue in order to avoid fragmentation and to achieve unity in international law. It is expected this judgment will be followed consistently by other tribunals to avoid fragmentation of legal principles. According to one commentator, the significance of the judgment

131 Churchill, supra note 56, at 138. 
transcends the interests of the two states as it is likely that many of the arguments employed by the Tribunal will apply equally to resolve other law of the sea disputes. ${ }^{132}$ Furthermore, through its judgment the ITLOS represented an expedient alternative to the other forums of disputes such as the ICJ or arbitration for the settlement of maritime disputes. ${ }^{133}$

Last but not the least, the judgment resolved a dispute amicably which is a positive development for the region.

132 Samuel J. Zeidman, Sittin' on the Dhaka the Bay: the Dispute Between Bangladesh and Myanmar and Its Implication for the International Tribunal for the Law of the Sea, 50 Columbia Journal of Transnational Law 442 (2012).

133 Id. at 484. 